\title{
Laguerre Kleimann, Michel. El oncenio y el desarrollo de la Armada peruana (1919-1930). Lima: Dirección de In- tereses Marítimos, 2015, $207 \mathrm{p}$.
}

De acuerdo con Lawrence A. Clayton, el Oncenio es tal vez el periodo de mayor cooperación entre Estados Unidos y Perú, gracias a la actitud pro-estadounidense del Presidente Augusto B. Leguía. (Clayton 2002: 213) Durante su gobierno, las relaciones bilaterales se ampliaran en áreas tan diversas como la aviación, la educación, la inversión y el comercio. Como bien ha documentado Miguel Laguerre Kleimann en su libro El Oncenio y el desarrollo de la Armada Peruana (19191930) (Lima: Dirección de Intereses Marinos, 2015), la Marina de Guerra del Perú fue una de las principales beneficiarias de tal cooperación.

El libro de Laguerre Kleimann enfoca el desarrollo de la Armada peruana en un periodo crucial de su historia, que conllevó su modernización gracias al apoyo del Presidente Leguía. Según el autor, el discurso capitalista que caracterizó al Oncenio se manifestó en la entrada de capital extranjero, principalmente estadounidense, e influyó el desarrollo de la Marina a través de un programa de modernización. Una pieza clave de tal programa fue la contratación, en 1920, de una misión naval estadounidense. El apoyo de Leguía generó simpatías de una parte de la oficialidad, especialmente entre los oficiales más jóvenes que le veían como un modernizador con conciencia naval. De acuerdo con el autor, Leguía buscó también modernizar la Armada como parte de un cálculo político para balancear el poder del Ejército.

Laguerre Kleimann divide su libro en tres capítulos. El primero lo dedica al análisis de la situación de la Armada perua- 
na desde la guerra con Chile hasta el año 1919. El segundo capítulo enfoca el desarrollo de una armada y de una doctrina naval estadounidenses estrechamente vinculadas a la expansión imperial de Estados Unidos a finales de siglo XIX. El último de sus capítulos está dedicado al examen de la reforma de la Armada Peruana por la misión estadounidense. Por razones de espacio me concentraré en el último capítulo.

Una de las preguntas principales de este estudio es por qué Leguía optó por contratar una misión naval estadounidense. Para el autor, el factor chileno parece ser crucial, pues alega que Leguía entendió la importancia de una marina de guerra fuerte como herramienta diplomática para lidiar con Chile y eso explica que buscara apoyo de "[...] la principal potencia naval y política del momento" para modernizar la Armada peruana (Laguerre 2015: 87). El autor juega con la idea de que Leguía abrió las puertas de su administración a funcionarios estadounidenses porque quería la ayuda de Estados Unidos para resolver los problemas asociados al incumplimiento del Tratado de Ancón. Leguía había prometido recuperar Tacna, Arica y Tarapacá, y no quería pagar el precio político que hubiera conllevado no hacerlo. En consecuencia, durante el Oncenio la Armada estuvo dirigida por marinos estadounidenses.

Laguerre Kleimann es muy claro al señalar, con toda razón,

310 que las misiones navales fueron instrumentos usados por las autoridades estadounidenses para promover y expandir sus objetivos e intereses, especialmente, en el periodo de entre guerras. Los estadounidenses buscaban puntos de apoyo logístico y expandir su acceso a materias primas y mercados en la región. En otras palabras, en la contratación y envío de una misión naval al Perú coincidieron los objetivos políticos de Leguía y los del imperialismo estadounidense. 
¿Cuál fue el impacto de la misión? De acuerdo con el autor, éste fue más allá del meramente técnico, ya que hubo lo que él denomina como "[...] una transferencia educacional y de etos" (Laguerre 2015: 186). Los marinos peruanos vieron a los oficiales estadounidenses como un "[...] modelo del progreso tecnológico y social a imitar" (Laguerre 2015: 186). De ahí que buscaran asimilar el American way of life que aquellos simbolizaban. Según Laguerre Kleimann, los marinos peruanos se identificaron con el progreso y la modernidad con el que igualaban a Estados Unidos. Sin embargo, este proceso de americanización no afectó el orgullo ni la identificación nacional de los peruanos. Estas claras simpatías por la forma de vida estadounidense explican porque la Marina ha sido la fuerza armada más inclinada a mantener relaciones estrechas con la nación estadounidense.

Puedo menos que concluir que este libro hace una importante y valiosa aportación al estudio de la historia de la Armada Peruana así como también al análisis de las relaciones peruano-estadounidenses en uno de sus periodos más importantes. Sin embargo, es necesario hacer algunas observaciones, especialmente, en lo relacionado al tema racial. Laguerre Kleimann comenta un informe del jefe de la misión estadounidense fechado el 24 de diciembre de 1925, cuatro años después de haber iniciado su trabajo en el Perú. Según el autor, el Contralmirante Clark H. Woodward señalaba que, a pesar de los defectos propios de los latinoamericanos que poseían los peruanos ([...] "patriotismo y lealtad barata, el arte de la mentira, celos profesionales, honestidad superficial, cierta crueldad heredada de sus Spanish ancestors, chauvinismo y oportunismo"), habían alcanzado progresos, especialmente en lo material "y en menor medida en lo moral y espiritual” (Laguerre 2015: 120). Para Woodward, según 
el autor, había un pequeño porcentaje "[...] con potencial de cortar con el aspecto negativo de la tradición, y trabajar y hablar con la verdad" (Laguerre 2015: 120). Este grupo, compuesto por el "15 o 20\% de la clase educada- "generally those with a touch of foreign blood-, está formado por gente que ha tenido la oportunidad de conocer otras realidades o de estudiarlas" (Laguerre 2015: 120).${ }^{1}$ El fuerte tono racial de estas citas es evidente y me sorprende que el autor no haga comentario alguno sobre este punto. Son claros los prejuicios de Woodward y me recuerdan comentarios similares sobre los filipinos hechos por oficiales militares estadounidenses a principios de siglo XX.

Por último, el autor señala que los informes de inteligencia que remitieron los miembros de la misión muestran el grado de profundidad con que éstos estudiaron a la sociedad peruana, y a la Marina en particular. Laguerre reconoce que "[...] los calificativos otorgados a los marinos peruanos pueden ser considerados como duros en principio, pero muestran el choque de culturas y las dificultades por las que tuvieron que pasar los distintos oficiales de la Misión en el cumplimiento de su tarea" (Laguerre 2015: 186-187). El autor no le presta atención al contexto estadounidense, es decir, a la sociedad de donde procedían esos oficiales, como tampoco a sus orígenes regionales ni de clase. De haberlo hecho, tendría una

312 explicación más compleja para un tema que creo iba más allá de los choques culturales y de la adaptación, y que apunta a un tema racial. Esos oficiales eran producto de una sociedad profundamente racista y ello debió influir en su interacción con los marinos peruanos. Sería interesante examinar esos

1 Énfasis del autor. 
reportes para reconstruir un discurso racial e ideológico, y compararles con la interacción de marinos y militares estadounidenses con sujetos del imperio formal estadounidense (Panamá, Puerto Rico, Cuba y/o las Filipinas) en el mismo periodo.

\section{Bibliografía}

CLAYTON, Lawrence A.

2002 Estados Unidos y el Perú: 1800-1995. Lima: Instituto Peruano de Economía Social de Mercado y Centro Peruano de Estudios Internacionales.

Norberto Barreto Velázquez. Centro de Investigación-Universidad del Pacífico 